\title{
The Study of Relations between Financial and Economic In Chinese Economic Development
}

\author{
Ai shuo ${ }^{1, a}$ \\ ${ }^{1}$ The property division, Shijiazhuang Vocational Technology Institute, Shijiazhuang, Hebei 050000, \\ China
}

a260002922@qq.com

Keywords: Financial, Economic, Chinese Economic Development, Relations

\begin{abstract}
Currently there are some negative tendencies of financial irrational development exist in some areas of China and cause a lot of harm. In this paper we put forward four strategic initiatives to deal with relations between financial and economic problems in China's economic development, namely: a clear position of financial in the Chinese economy, promote the construction of China inclusive financial system, play the role of finance to implement the national strategy and strengthen top-level design and guide of financial system construction.
\end{abstract}

\section{Introduction}

Since the reform and opening up, Comrade Deng Xiaoping's "Finance is the core of modern economy," under the guiding ideology, the rapid development of China's financial sector, the financial system continues to improve, significantly expanded the scale of the financial markets, a substantial increase in the total financial value of the financial international status rapidly. Through monetization to drive commodity production and facilitate trade in goods, by credit of promoting capital accumulation and optimize the allocation of capital, and the contribution of the industrial development process of its own added value, finance has become an essential element and an important driving force of China's economic development. The continuous development of China's financial industry to grow and to optimize the allocation of resources to support the economic reforms, and promote stable and rapid economic development and the maintenance of social stability has played an important role.

However, a period of time, there has been the development of financial irrational tendency in some areas China, bringing the potential risks and hazards. Therefore, a more comprehensive and accurate understanding of "Finance is the core of modern economy" thesis, and handle the relationship between finance and the economy in China's economic development has important and far-reaching significance [1].

\section{The Financial Irrational Development in China's Economic Development and Its Jeopardize}

Large-scale industrial capital permeates to finance. In recent years, China's financial sector to attract relatively high profit levels and a relatively fast rate of profit, the entry point for all kinds of industrial capital have sought to participate in the financial sector. At present, the degree of partial industrial capital to participate in the financial industry has been far beyond the normal need of services the main industry, showing a profit even speculative characteristic. Especially in some large state-owned enterprises to develop the financial sector through its subsidiaries or shareholding companies, in fact, has indirectly acquired the banking industry "fully licensed business qualification.

Industrial capital participation in the financial sector, achieve moderate the Combination, can promote the industrial capital efficiencies. However, the industrial capital, especially in relation to the country's economic lifeline of state-owned large and medium industry companies seek to penetrate to the financial sector, if excessive deviation from the main business, there is a huge hazard: First, the excessive involvement of the financial sector industrial capital, no doubt dispersion of limited management resources, is not conducive to corporate focus and stronger the main industry. 
Second, the financial sector has a high risk of natural features, such as excessive involvement of industrial capital, industrial capital is bound to increase the risk faced by the industry could destabilize the basis of security to some extent. Third, under China's current financial regulatory model, industrial capital was heavily involved in the financial sector also greatly increased supervision and regulation of financial difficulty, which is not conducive to maintaining a stable financial order [2].

The local government' blindness of financial planning. As efforts to attract financial capital, give full play to the role of financial radiation and enhance the city's image, China has accumulated more than 30 cities have proposed the establishment of a financial center planning at all levels. While in China is a vast and unbalanced regional economic development situation, the establishment of the hierarchy levels and covering a variety of financial centers in different regions has its rationality, but in China's current stage of economic and financial developments, dozens of cities proposed financial center The construction plan apparently is blind and lack of scientific nature.

Local government is keen to build a financial center of the phenomenon there are many potential risks or drawbacks: First, many cities focus on building a financial center, the financial center is completed, there is inevitably overlap functionality and coverage area, bringing the problem of redundant construction, and caused unnecessary waste of financial, human and other resources, weakening the potential for economic development of local entities. Second, the local government for the rapid completion of the financial center, is easy to "go faster" to build new trading markets and financial institutions and other hardware facilities, but ignore system construction, personnel, and cultural and other financial software environment, which may lead to imbalance in the local financial system Financial efficiency is therefore reduce the financial risk will also increase substantially. Third, local governments compete to attract financial resources to enter this area, there may have been introduced too promotions and incentives quite reasonable, and the formation of local financial protectionism bring vicious competition between local, eventually leading financial center functions distortion [3].

Continuous wave of speculation. In recent years, China's economy relative excess liquidity environment has emerged in different areas of abnormal wave of speculation and hype, real estate, bulk agricultural products, herbs, and other high-end works of art has become the object of speculation, and this speculative wave it seems there is still a tendency to spread to more areas.

Wave of speculation brought about the emergence and spread a lot of negative consequences: the abnormal development of the real estate industry has been seriously affected the stable macroeconomic development and welfare of the common people; fluctuations in prices for agricultural commodities seriously interfere with the price system, which greatly exacerbated the macroeconomic regulation and control difficulty, but also seriously harm the vital interests of the majority of ordinary farmers. Prevailing wind speculation and speculation continues to attract more and more ordinary people involved, but the real profit is only possible to include international hot money, including large investors or speculators, but ordinary people can only become final "bill by".

Wave of speculation is an important manifestation of commodity finance and a substantial price spread will lead to system disorders, endangering mechanism microeconomic operations, and make it harder to achieve steady and rapid financial and economic development. At the same time, more and more businesses and residents to participate in short-term financial speculation, the more money and resources into the financial sector, trying to rely on financial speculation flourishes, while industrial investment and capital accumulation dismissive. Wave of speculation in vogue, not only to a certain extent undermines the foundations of long-term sustainable development of the real economy, but also with the construction of socialist core value system requirements are contrary.

Non-formal private financial development should be standardized. In the recent period, the risk of non-formal private finance China began to focus on long-term accumulation appear: Bank credit funds involved in loan-sharking, usury listed companies involved, usury and other civil servants to join the incidents continue to occur; private finance relatively developed areas, frequent participant usury due to funding strand breaks and fled even suicide cases. Moderate development of private finance can promote economic development, but in fact such as Wenzhou, Ordos and other 
parts of the private financial development has deviated from the normal track, non-formal usury huge, potential risks and hazards gradually exposed, which the above-mentioned areas overall relationship between financial and economic development to grasp properly, the lack of private finance appropriate guidance and norms, while allowing private finance self-development are closely related.

Informal private financial problems, the impact on China's financial stability and economic development enormous: first, the current majority of private finance activities in a "semi-underground, opaque" state, private finance expanding, increasing the relevant department statistics, policy and financial regulation more difficult, is not conducive to maintaining financial stable development and financial risks. Two informal private finance with the "high cost, difficult rollover" features, many obtain funding through this channel business, once the capital strand breaks phenomenon, easily lead to bankruptcy of enterprises closed, which is obviously not conducive to industrial economy steady development. Third, the private financial actors with the "universality, people-oriented" features, once risk concentrated outbreak and rapid spread easily lead to social groups, events, endangering social stability [4].

\section{Correctly handle the relationship between financial and economic in China's economic development}

Clear positioning the financial position in the Chinese economy. The financial sector, essentially belongs to the category of the virtual economy services, it is dependent on the development of the real economy and the service industry. Nevertheless, at different stages of economic development, financial status plays a role in economic development which should be differentiated.

During China's current economy is still in the beginning of the socialist market economy, the adjustment, promote scientific and technological progress and innovation, the development of strategic emerging industries, protect and improve people's livelihood, the transformation of economic development, enhance the comprehensive national strength and other "five" or more long-term strategic objectives process, the clear positioning of financial position in China's economy is very important.

Promote the construction of China inclusive financial system. Status of pilot services in the financial industry should first and foremost meet the needs of China's economic development, in order to better serve the realization of China's economic development goals, the financial system needs to constantly optimize and improve according to the status of economic development needs.

Currently, the presence of Chinese economic development "dual economy" characterized corresponds to the financial sector are also "dual financial" phenomenon, mainly reflected in two aspects: First, the regional distribution of financial resources is very uneven, the eastern region and the cities financial infrastructure is far ahead of its corresponding central and western regions and towns in rural areas. Second, the market position of a significant gap between the market participants, large-scale enterprises to obtain financial support and services significantly more than the convenience of SMEs, large institutional investors to invest in financial channels obviously rich people in the general population. There is no doubt that this "dual financial" situation will further aggravate the imbalance in China's current economic development already exist, impede the realization of China's economic development goals. Therefore, changing the development pattern of the current "dual finance", accelerate the construction of an inclusive financial system has become a major issue and the formation of the current Chinese financial development process.

Play the role of finance to implement the national strategy. Implement national strategy refers to surpass the domestic economy Development Goals, the international community continues to enhance China's comprehensive national strength and international influence. Currently, the competition between countries to reflect the competition in comprehensive national strength and the financial strength and is an important reference and determinants.

When the degree of China's participation in economic globalization deepens the background, there is no doubt that China's economic and financial development should be both inside and outside, 
internally and externally. China, as a big developing country, to first put their own affairs well, smooth dealing with economic development, structural adjustment and prevent inflation relationship and achieve comprehensive, coordinated and sustainable economic development. Comprehensively promote financial reform and opening up, and properly deal with new situations and new problems emerging, it is possible while promoting China's domestic economic goals, and the progressive realization of China's national strategic goals in the international arena.

Strengthen the top-level design and guide of financial system construction. The correct positioning of the financial status of the implementation of building an inclusive financial system and the role of other financial strategies in achieving national strategic initiatives inevitably require the financial industry to accelerate the reform to further improve China's financial system [5].

This is because, since the reform and opening up in spite of the financial industry has been considerable progress, but still a lot of issues: financial market is not high; lack of financial innovation, overall less competitive; financial market development structural imbalances, low proportion of direct financing, urban and rural, regional financial development uncoordinated, "three rural" and financial services for SMEs is relatively weak; financial corporate governance, internal control, risk management needs to be improved, the operating mechanism has not been a fundamental change and so on. There is no doubt that China's financial system there are still many institutional mechanisms, structural and other deep-rooted problems, to further change the financial development mode, deepen financial reform, to encourage financial innovation, improve financial services, strengthening financial supervision. Give full play to the financial function and guard against financial risks, taking into account the development of domestic and foreign financial goals more difficult. Therefore, the strengthening of the financial system construction of China's top-level design and guidance, many of the objectives of the co-ordination and effectively guard against financial risks, it is very necessary [6].

\section{Conclusion}

China's economic development is far from the stage of modern economy. After 30 years of reform and opening up, China's economic had a sustained and rapid growth, the economy has leapt to second in the world, the overall trend of economic development is still relatively good. Nevertheless, it is undeniable that China's current economic development market is far from mature, it is still in the primary stage of the socialist market economy and the level of economic development is still far away the requirements of the modern economy. So we must have a clear understanding on the basic situation of China's economic development to accelerate the pace of economic development.

\section{References}

[1] X.L.Wu, The top-level design and financial reform, J. 21st Century Business Herald. 8 (2011) 25-30.

[2] F.Z.Xie, Grasp the five characteristics of the modern economy, J. Industrial Audit. 18(2003) 55-57.

[3] C.G.Xu, Chinese economic issues: from the institutional to the structure, J. Southern Metropolis Daily, 32(2012) 189-190.

[4] X.X.Xu, The inequality evolution trend of Chinese urban residents, J, Sociological Research, $4(2007) 38-40$.

[5] X.T.Tian, The international environmental assessments of China's rise, J. Strategy and Management, 9(2013) 142-150. 